\title{
PERENCANAAN PEMBANGKIT LISTRIK TENAGA MIKROHIDRO DI SALURAN IRIGASI MATARAM
}

\author{
Titis Haryani, Wasis Wardoyo, Abdullah Hidayat SA. \\ Jurusan Teknik Sipil, Fakultas Teknik Sipil dan Perencanaan, Institut Teknologi Sepuluh Nopember (ITS) \\ J1. Arief Rahman Hakim, Surabaya 60111 Indonesia \\ e-mail: titisharyani@gmail.com ; wasis@ce.its.ac.id
}

\begin{abstract}
Abstrak - Saluran Irigasi Mataram adalah saluran irigasi yang menghubungkan Sungai Progo di Yogyakarta sebelah Barat dan Sungai Opak di Yogyakarta sebelah Timur. Meskipun letaknya strategis, namun potensi aliran air di Saluran Irigasi Mataram belum dimanfaatkan secara maksimal dalam hal pembangkit listrik tenaga air. Menurut kapasitas daya yang dihasilkan, ada beberapa macam pembangkit listrik tenaga air, salah satunya adalah Pembangkit Listrik Tenaga Mikrohidro. Pembangkit Listrik Tenaga Mikrohidro adalah pembangkit listrik skala kecil dengan daya kurang dari 100 KW. Tenaga air yang digunakan dapat berupa aliran sungai yang dibendung, air terjun, dan aliran air pada sistem irigasi. Ditinjau dari ketersediaan air di Saluran Irigasi Mataram, yaitu debit andalan $85 \%$ sebesar $1,7 \mathrm{~m}^{3} / \mathrm{detik}$ dan beda tinggi sebesar 3,56 meter, Saluran irigasi Mataram berpotensi untuk dibangun Pembangkit Listrik Tenaga Mikrohidro. Perencanaan Pembangkit Listrik Tenaga Mikrohidro ini berdasarkan pada studi literatur, survei lapangan, dan analisa data.
\end{abstract}

Dari perencanaan Pembangkit Listrik Tenaga Mikrohidro ini akan menghasilkan daya sebesar 59,37 kW dan energi listrik yang dihasilkan sebesar 358938, $69 \mathrm{KWH}$ per tahun.

\section{PENDAhuluan}

Kebutuhan energi semakin meningkat sejalan dengan kemajuan zaman. Salah satu bentuk energi yang tidak dapat terlepas dari kehidupan manusia adalah energi listrik. Sumber energi listrik yang sudah lazim dipergunakan adalah sumber energi minyak bumi, gas alam, dan batu bara, sedangkan sumber energi air, panas bumi, panas matahari, dan nuklir masih terus dikembangkan. Sebagaimana yang telah diketahui bahwa persediaan sumber energi minyak bumi, gas alam, dan batu bara sangat terbatas dan apabila digunakan secara terus-menerus maka suatu saat sumber energi tersebut akan habis.

Air merupakan sumber energi yang berpotensi besar sebagai pembangkit listrik. Pembangkit listrik tenaga air semakin strategis sebagai salah satu sumber energi terbarukan, mengingat potensi sumber energi dari fosil dan batu bara akan semakin berkurang. Ada beberapa jenis pembangkit listrik berdasarkan kapasitasnya yaitu sebagai berikut:
a. PLTA mikro $<100 \mathrm{~kW}$
b. PLTA mini $100-999 \mathrm{~kW}$
c. PLTA kecil 1000-10.000 kW
d. PLTA besar $>10.000 \mathrm{~kW}$

Indonesia adalah negara kepulauan dimana masih banyak daerah terpencil yang belum terjangkau oleh PLN sedangkan listrik sangat dibutuhkan agar daerah tersebut maju dan meningkat produktifitas masyarakatnya. Oleh karena itu untuk memenuhi kebutuhan listrik daerah terpencil perlu diciptakan alat yang dapat menjangkau tempat terpencil yang murah dan ramah lingkungan, yaitu Pembangkit Listrik Tenaga Mikrohidro.

Pembangkit Listrik Tenaga Mikrohidro atau yang sering disingkat PLTMH, yaitu pembangkit listrik skala kecil dengan daya kurang dari $100 \mathrm{KW}$ yang memanfaatkan tenaga air sebagai sumber penghasil energi. (Patty, 1995) PLTMH termasuk sumber energi terbarukan dan layak disebut clean energy karena ramah lingkungan. Dari segi teknologi PLTMH dipilih karena konstruksinya sederhana, mudah dioperasikan, serta mudah dalam perawatan dan penyediaan suku cadang. Secara ekonomi, biaya operasi dan perawatannya relatif murah sedangkan biaya investasinya cukup bersaing dengan pembangkit listrik lainnya. Secara sosial, PLTMH mudah diterima masyarakat luas. PLTMH biasa dibuat dalam skala desa di daerah-daerah terpencil yang belum mendapatkan listrik dari PLN. Tenaga air yang digunakan dapat berupa aliran air pada sistem irigasi, sungai yang dibendung atau air terjun. Di Kecamatan Ngluwar, Kabupaten Magelang dimana terdapat bendung Karangtalun atau biasa masyarakat menyebutnya dengan bendung Ancol Bligo yang membendung sungai Progo. Bendung Karangtalun mengaliri $30000 \mathrm{Ha}$ areal pertanian. Bendung Karangtalun memiliki dua pintu pengambilan (intake), pintu pengambilan sebelah kiri mengaliri saluran irigasi Mataram sedangkan pintu pengambilan sebelah kanan mengaliri saluran 


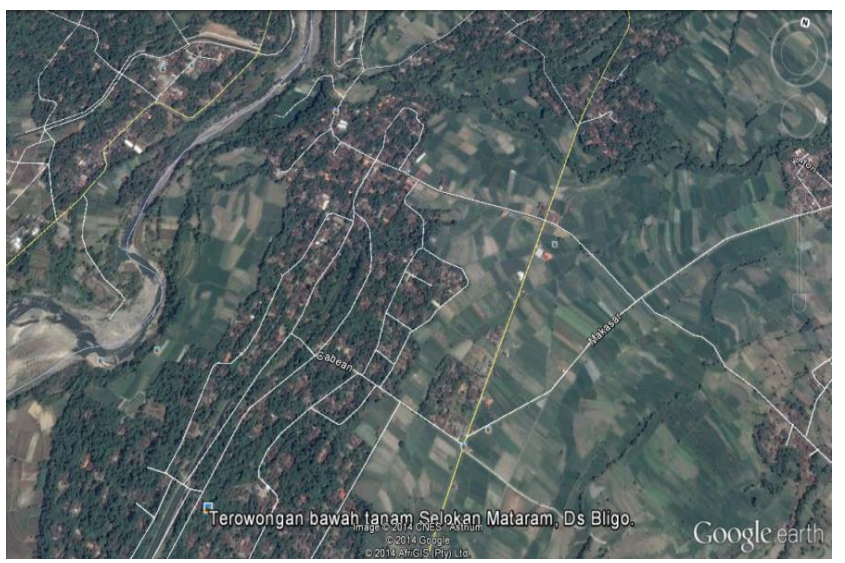

Gambar 1. Desa Bligo, Kec Ngluwar, Kab Magelang

(Sumber: Google Earth, 2014)

irigasi Kali Bawang. Sebagian besar penduduk di sana bermata pencaharian sebagai petani.

Saluran irigasi Mataram atau yang sering disebut dengan selokan Mataram oleh masyarakat Yogyakarta dan sekitarnya adalah saluran irigasi yang menghubungkan Sungai Progo di Yogyakarta sebelah Barat dan Sungai Opak di Yogyakarta sebelah Timur. Pintu pengambilan saluran irigasi Mataram terletak di sebelah hulu bendung Karangtalun yang dibangun pada tahun 1976-1979. Jaringan Induk saluran irigasi Mataram panjangnya $3 \mathrm{~km}$, membentang dari Bendung Karangtalun di Karangtalun, Ngluwar, Magelang sampai pintu sadap saluran irigasi Mataram II (Van Der Wijck) di sisi timur Desa Bligo, Ngluwar, Magelang.

Balai PSDA WS POO Dinas PU DIY menginformasikan, panjang keseluruhan sistem irigasi Mataram dari Kali Progo hingga Kali Opak adalah $42 \mathrm{~km}$. Sistem Irigasi Mataram terdiri 1 unit bendung, 3 jaringan irigasi utama, 1 terowongan di bawah dusun, 9 unit penguras, 85 lokasi unit sadap, 24 lokasi unit suplesi, 5 lokasi unit penyaring, 3 sipon (terowongan dibawah sungai), dan 24 talang (bangunan di atas sungai).

Pada $7^{\circ} 40^{\prime} 13.24$ 'S $110^{\circ} 16^{\prime} 02.60^{\prime \prime} \mathrm{T}$ yang termasuk dalam wilayah Desa Bligo, Kecamatan Ngluwar, Kabupaten Magelang dan masih dalam kawasan hulu dari saluran irigasi Mataram terdapat beda tinggi yang cukup signifikan untuk dapat dibangun PLTMH. Latar belakang di atas mengantarkan penulis sampai pada judul tugas akhir "Perencanaan Pembangkit Listrik Tenaga Mikrohidro di Saluran Irigasi Mataram"

Hal 76

\section{TINJAUAN PUSTAKA}

\section{Analisa Debit Andalan}

Debit andalan adalah debit dengan tingkat keandalan tertentu yang direncanakan sebagai sumber air untuk operasional PLTMH. (Sulaiman, 2012)

Untuk menentukan besarnya debit andalan dibutuhkan seri data debit yang panjang yang dimiliki oleh setiap stasiun pengamatan debit. Metode yang sering dipakai untuk analisis debit andalan adalah metode statistik (rangking). Penetapan rangking dilakukan menggunakan analisis probabilitas dengan rumus Weibul. Debit andalan $80 \%$ berarti bahwa probabilitas debit tersebut untuk disamai atau dilampaui sebesar $80 \%$ yang berarti juga bahwa kegagalan kemungkinan terjadi dengan probabilitas sebesar 100\% dikurangi $80 \%$ atau boleh dikatakan sebesar 20\%.(Budiyanto,2013)

Setelah diperoleh debit andalan, maka selanjutnya debit andalan tersebut digunakan untuk perhitungan kapasitas tenaga air.

\section{Perencanaan Kapasitas Tenaga Air}

Kapasitas tenaga air adalah kemampuan tenaga air memproduksi daya listrik. Kapasitas pembangkit listrik tenaga mikrohidro ditentukan dari debit yang dialirkan ke pembangkit dan tinggi jatuh efektif yang ada. Debit yang diambil adalah debit andalan dan tinggi jatuhnya diusahakan semaksimal mungkin berdasarkan kondisi topografi. Berikut adalah cara perhitungan tinggi jatuh efektif dan daya yang dihasilkan:

1. Tinggi jatuh efektif

Tinggi jatuh efektif diperoleh dengan mengurangi tinggi jatuh air total (dari permukaan air pada pengambilan sampai permukaan air yang masuk ke turbin) dengan kehilangan tinggi pada saluran air dapat dirumuskan:

$H_{\text {bruto }}=$ elevasi upstream - elevasi downstream

$H_{\text {losses }} \quad=10 \% \times \mathrm{H}_{\text {bruto }}$

$H_{\text {eff }}=H_{\text {bruto }}-H_{\text {losses }}$

dimana:

$H_{\text {bruto }} \quad=$ perbedaan tinggi muka air di hulu dan hilir

$H_{\text {losses }} \quad=$ tinggi kehilangan energi

Untuk mendapatkan hasil yang optimal, maka sistem pembangkit harus didesain sedemikian hingga sehingga tekanan maksimal 10\% dari head bruto. (Patty, 1995) 
2. Daya yang dihasilkan

Daya adalah usaha yang dihantarkan per satuan waktu. Dalam perencanaan PLTMH, daya diperoleh dengan menggunakan rumusan:

$\mathrm{P}=\mathrm{\eta} \times \rho \times \mathrm{g} \times H_{e f f} \times \mathrm{Q}$

(watt)

dimana:

$\mathrm{P} \quad=$ perkiraan daya yang dihasilkan $(\mathrm{kW})$

$$
1 \text { watt }=\frac{1 \mathrm{~J}}{\mathrm{~s}}=\frac{1 \mathrm{Nm}}{\mathrm{s}}=\frac{1 \mathrm{Kg} \mathrm{m} \mathrm{m}^{2}}{\mathrm{~s}^{3}}
$$

$\rho \quad=$ massa jenis air $\left(1000 \mathrm{~kg} / \mathrm{m}^{3}\right)$

$\mathrm{g} \quad=$ percepatan gravitasi $\left(9,81 \mathrm{~m} / \mathrm{detik}^{2}\right)$

$\mathrm{Q} \quad=$ debit andalan $\left(\mathrm{m}^{3} /\right.$ detik)

$H_{\text {eff }}=$ tinggi jatuh efektif $(\mathrm{m})$

(Patty, 1995)

Perkiraan daya yang dihasilkan digunakan sebagai asumsi sementara untuk perhitungan selanjutnya.

A. Perencanaan Bangunan Pembangkit

Beberapa komponen yang direncanakan untuk Pembangkit Listrik Tenaga Mikrohidro antara lain: bangunan pengatur tinggi muka air, pintu pengambilan (intake), saluran pembawa (headrace), bangunan ukur, bak penenang (forebay), pipa pesat (penstock), turbin, dan saluran pembuangan (tailrace). (Kusdiana,2008)

B. Estimasi Kehilangan Energi

Dalam perjalanan air mengalir dari pintu pengambilan hingga pipa pesat, akan terjadi kehilangan energi seperti kehilangan energi karena saringan kasar, kehilangan energi pada entrace, kehilangan energi karena gesekan sepanjang pipa, dan kehilangan energi karena belokan pipa. (Triatmodjo,1993)

C. Perhitungan Energi Listrik

Energi listrik total dihitung dengan rumusan sebagai berikut:

$$
\begin{aligned}
& \mathrm{E} \quad=\mathrm{P} \times \mathrm{t} \\
& \text { dengan: } \\
& \mathrm{E} \quad=\text { Energi dalam satu tahun }(\mathrm{kWh}) \\
& \mathrm{P} \quad=\text { Daya }(\mathrm{kW}) \\
& \mathrm{t} \quad=\text { waktu }(\mathrm{jam})=365 \text { hari } \times 24 \text { jam }
\end{aligned}
$$

\section{METODOLOGI}

\section{A. Umum}

Pengerjaan tugas akhir ini berdasarkan pada studi literatur, survei lapangan, dan analisa. Adapun langkah-langkah dan prosedur penyusunan tugas akhir ini secara berurutan dapat dipaparkan sebagai berikut:

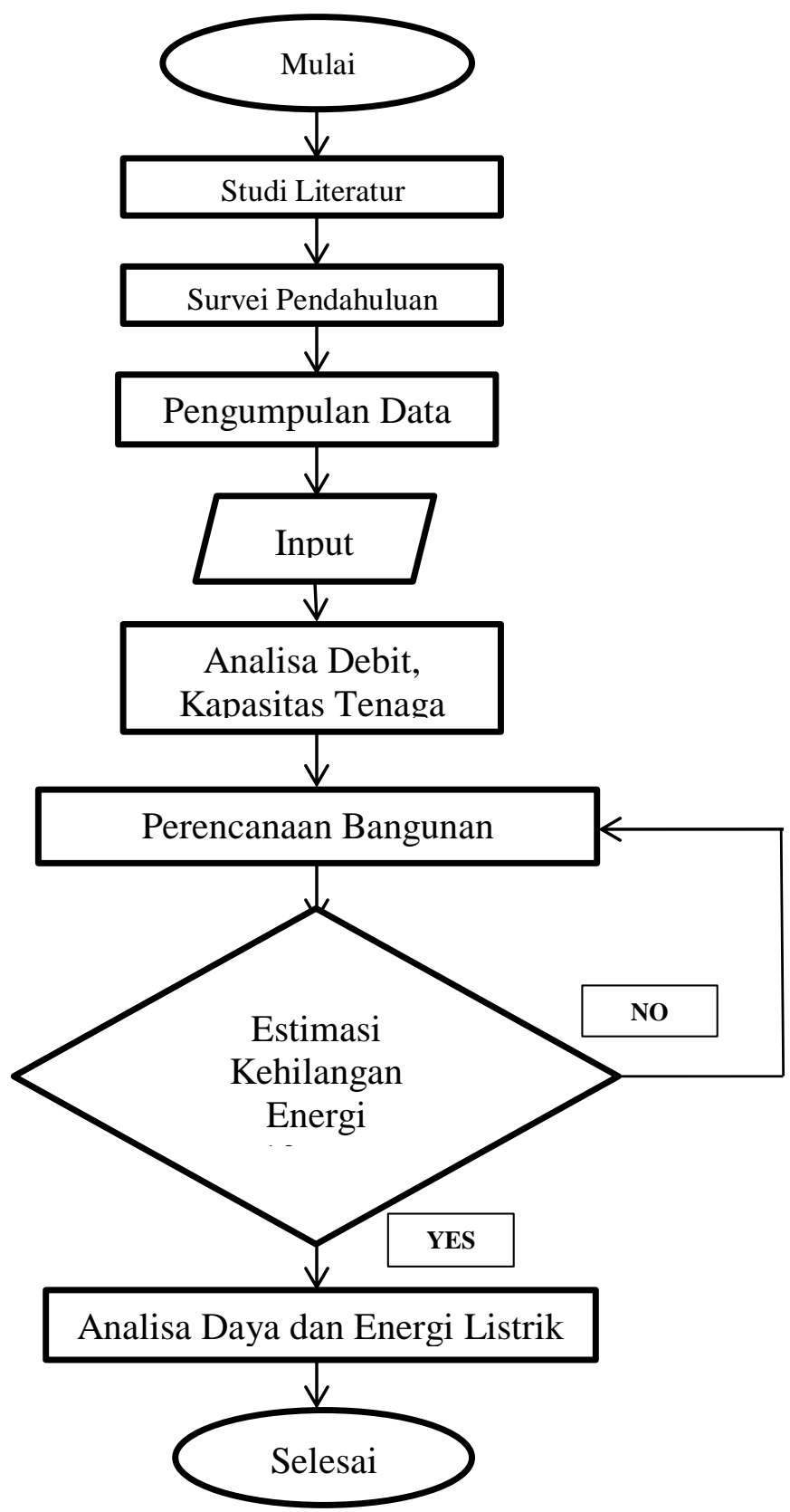

Gambar 2. Bagan Alir Metodologi

\section{ANALISA DAN PERENCANAAN}

\section{Analisa Debit Andalan}

Data yang akan digunakan dalam analisa merupakan data debit selama 10 tahun. Berikut adalah rekapitulasi data debit Saluran Irigasi Mataram dari tahun 2004-2013: 
Tabel 1. Rekapitulasi data debit dalam 10 tahun

\begin{tabular}{|c|c|c|c|c|c|}
\hline No & $\begin{array}{c}\text { Interval } \\
\left(\mathrm{m}^{3} / \text { detik }\right)\end{array}$ & $\begin{array}{c}\text { Nilai Tengah } \\
\left(\mathrm{m}^{3} / \text { detik }\right)\end{array}$ & Frekuensi & Frekuensi Kumulatif & $\begin{array}{c}\text { Probabilitas } \\
(\%)\end{array}$ \\
\hline 1 & $17,693-15,165$ & 16,429 & 69 & 69 & 57,50 \\
\hline 2 & $15,164-12,636$ & 13,900 & 24 & 93 & 77,50 \\
\hline 3 & $12,635-10,107$ & 11,371 & 6 & 99 & 82,50 \\
\hline 4 & $10,106-7,578$ & 8,842 & 0 & 99 & 82,50 \\
\hline 5 & $7,577-5,049$ & 6,313 & 2 & 101 & 84,17 \\
\hline 6 & $5,048-2,520$ & 3,784 & 0 & 101 & 84,17 \\
\hline 7 & $2,519-0$ & 1,260 & 19 & 120 & 100,00 \\
\hline
\end{tabular}

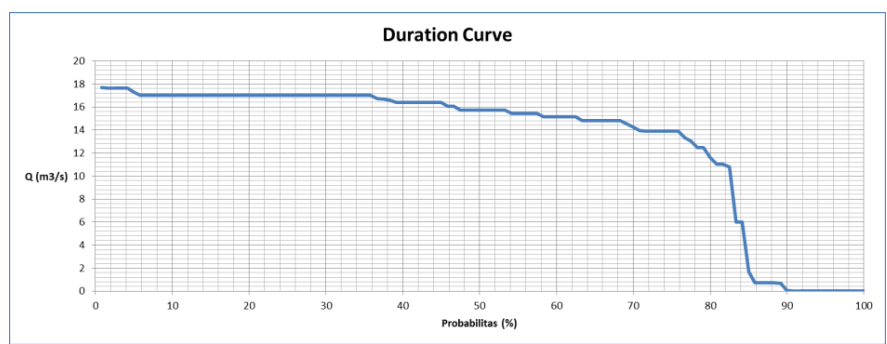

Gambar 3. Duration Curve

Setelah dilakukan simulasi, maka diambil debit andalan $85 \%$ yaitu pada debit $1,70 \mathrm{~m}^{3} /$ detik. Nilai terkecil yang masih sanggup menggerakkan turbin adalah nilai $15 \%$ dari debit andalan, yaitu:

$Q_{\min }=15 \% \times 1,70 \mathrm{~m}^{3} /$ detik $=0,255 \mathrm{~m}^{3} /$ detik

\section{A. Perencanaan Kapasitas Tenaga Air}

Kapasitas daya ditentukan oleh debit yang mengalir dalam saluran dan tinggi jatuh yang ada.

1. Tinggi jatuh efektif

Tinggi jatuh efektif didapat dengan memperhitungkan kehilangan energi. Dalam perencanaan awal akan diambil kehilangan energi sebesar $10 \%$ dari tinggi bruto sebagai asumsi awal. (Eko,2011)

$H_{\text {bruto }}=$ elevasi upstream - elevasi downstream

$$
\begin{aligned}
& =146,65-142,70 \\
& =3,95 \mathrm{~m} \\
H_{\text {losses }} & =10 \% \times H_{\text {bruto }} \\
& =10 \% \times 3,95 \mathrm{~m} \\
& =0,395 \mathrm{~m}
\end{aligned}
$$

sehingga perkiraan awal tinggi jatuh efektif akan diperoleh sebesar

$$
\begin{aligned}
H_{\text {eff }} & =H_{\text {bruto }}-H_{\text {losses }} \\
& =3,95 \mathrm{~m}-0,395 \mathrm{~m} \\
& =3,56 \mathrm{~m}
\end{aligned}
$$

dimana:

$$
\begin{aligned}
& H_{\text {eff }} \quad=\text { tinggi jatuh efektif }(\mathrm{m}) \\
& H_{\text {bruto }}=\text { tinggi bruto }(\mathrm{m}) \\
& H_{\text {losses }}=\text { tinggi kehilangan energi }(\mathrm{m})
\end{aligned}
$$

2. Daya yang dihasilkan

Dari data debit andalan dan tinggi jatuh efektif akan didapat daya yang dihasilkan.

$$
\begin{aligned}
& P=\rho \times \mathrm{g} \times Q_{\text {andalan }} \times H_{e f f} \\
& =1000 \mathrm{~kg} / \mathrm{m}^{3} \times 9,81 \mathrm{~m} / \mathrm{s}^{2} \times 1,70 \mathrm{~m}^{3} / \mathrm{s} \times 3,56 \mathrm{~m} \\
& =59370,12 \mathrm{~kg} \mathrm{~m}^{2} / \mathrm{s}^{3} \\
& =59370,12 \text { watt } \\
& =59,37 \mathrm{~kW} \\
& \text { dimana: } \\
& P \quad=\text { perkiraan daya yang dihasilkan }(\mathrm{kW}) \\
& \rho=\text { massa jenis air }\left(\mathrm{kg} / \mathrm{m}^{3}\right) \\
& \mathrm{g} \quad=\text { gaya gravitasi }\left(9,81 \mathrm{~m} / \text { detik }^{2}\right) \\
& Q_{\text {andalan }}=\text { debit andalan }\left(\mathrm{m}^{3} / \text { detik }\right) \\
& H_{\text {eff }} \quad=\text { tinggi efektif }(\mathrm{m})
\end{aligned}
$$

B. Perencanaan Bangunan Pembangkit

Beberapa komponen yang direncanakan untuk Pembangkit Listrik Tenaga Mikrohidro antara lain: bangunan pengatur tinggi muka air, pintu pengambilan (intake), saluran pembawa (headrace), bangunan ukur, bak penenang (forebay), pipa pesat (penstock), turbin, dan saluran pembuangan (tailrace).

1. Perencanaaan bangunan pengatur tinggi muka air

Bangunan pengatur tinggi muka air terletak melintang pada saluran dan berada di depan pintu pengambilan (intake). Bangunan ini berfungsi untuk mengatur tinggi muka air di saluran depan intake sehingga debit yang masuk intake sesuai dengan perencanaan yaitu debit andalan. (Soesanto,2010) Bangunan pengatur tinggi muka air direncanakan dengan skot balok. Skot balok diletakkan melintang saluran setinggi rencana dan debit yang berlebih akan melimpah melalui atas balok ke saluran eksisting. Dari tabel hubungan $\mathrm{h}$ dan $\mathrm{Q}$ diperoleh tinggi muka air saat debit andalan adalah $0,65 \mathrm{~m}$, maka elevasi muka air di depan pintu intake adalah $+146,65+0,65=+147,3$. Tinggi skot balok disesuaikan dengan yang ada di pasaran yaitu $(20 \mathrm{~cm}$ $\mathrm{x} 10 \mathrm{~cm}$ ) sehingga dipasang 4 skot balok dengan tinggi skot balok 0,8 meter dari dasar saluran.

2. Perencanaan pintu pengambilan (Intake)

Pintu pengambilan berfungsi untuk memasukkan debit rencana dari saluran. Pintu intake direncanakan menggunakan pintu sorong dengan tipe pintu pengambilan aliran tidak tenggelam. 
Tabel 2. Rekapitulasi Perhitungan Pintu Intake

\begin{tabular}{|l|c|c|c|}
\hline \multicolumn{1}{|c|}{ Parameter } & Notasi & Nilai & Satuan \\
\hline Tinggi pintu & $h_{p}$ & 0,75 & $\mathrm{~m}$ \\
\hline $\begin{array}{l}\text { Beda kedalaman } \\
\text { air }\end{array}$ & $z$ & 0,14 & $\mathrm{~m}$ \\
\hline
\end{tabular}

3. Perencanaan saluran pembawa (Headrace)

Saluran pembawa merupakan saluran terbuka berbentuk persegi yang mengalirkan debit sebesar debit andalan.

Pada saluran pembawa, debit air diukur menggunakan bangunan ukur untuk mengetahui banyaknya debit yang melewati saluran pembawa.

Tabel 3. Rekapitulasi Perhitungan Headrace

\begin{tabular}{|l|c|c|c|}
\hline \multicolumn{1}{|c|}{ Parameter } & Notasi & Nilai & Satuan \\
\hline $\begin{array}{l}\text { Debit } \\
\text { rencana }\end{array}$ & Qandalan & 1,70 & $\mathrm{~m}^{3} /$ detik \\
\hline Kecepatan & $v$ & 0,5 & $\mathrm{~m} /$ detik \\
\hline $\begin{array}{l}\text { Koefisien } \\
\text { manning }\end{array}$ & $n$ & 0,015 & - \\
\hline Lebar saluran & $b$ & 3 & $\mathrm{~m}$ \\
\hline $\begin{array}{l}\text { Tinggi } \\
\text { saluran }\end{array}$ & $h$ & 1,5 & $\mathrm{~m}$ \\
\hline $\begin{array}{l}\text { Kemiringan } \\
\text { dasar saluran }\end{array}$ & $S$ & 0,0001188 & - \\
\hline Tinggi jagaan & $w$ & 0,6 & $\mathrm{~m}$ \\
\hline
\end{tabular}

4. Perencanaan bangunan ukur

Bangunan ukur diperlukan untuk mengukur banyaknya debit air yang akan digunakan PLTMH. Bangunan ukur direncanakan mampu mengukur sampai debit minimum.

Tabel 4. Rekapitulasi Perhitungan Bangunan Ukur

\begin{tabular}{|l|c|c|c|}
\hline \multicolumn{1}{|c|}{ Parameter } & Notasi & Nilai & Satuan \\
\hline Debit rencana & $Q_{\text {andalan }}$ & 1,70 & $\mathrm{~m}^{3} /$ detik \\
\hline Lebar alat ukur & $b$ & 3 & $\mathrm{~m}$ \\
\hline Kecepatan & $v$ & 0,5 & $\mathrm{~m} /$ detik \\
\hline $\begin{array}{l}\text { Tinggi air batas } \\
\text { ambang }\end{array}$ & $h$ & 0,48 & $\mathrm{~m}$ \\
\hline $\begin{array}{l}\text { Tinggi energi } \\
\text { hulu }\end{array}$ & $H_{1 \text { maks }}$ & 0,5 & $\mathrm{~m}$ \\
\hline $\begin{array}{l}\text { Panjang alat } \\
\text { ukur }\end{array}$ & $L$ & 1 & $\mathrm{~m}$ \\
\hline Jari-jari & $r$ & 0,1 & $\mathrm{~m}$ \\
\hline
\end{tabular}

5. Perencanaan bak penenang (Forebay)

Bak penenang berfungsi untuk mengontrol perbedaan debit dalam pipa pesat (penstock) dan saluran pembawa karena fluktuasi beban, disamping itu juga sebagai pemindah sampah terakhir (tanah, pasir, kayu yang mengapung) dalam air yang mengalir. Bak penenang dilengkapi dengan saringan (trashrack).

Tabel 5. Rekapitulasi Perhitungan Forebay

\begin{tabular}{|l|c|c|c|}
\hline \multicolumn{1}{|c|}{ Parameter } & Notasi & Nilai & Satuan \\
\hline Panjang bak & $L f$ & 5 & $\mathrm{~m}$ \\
\hline $\begin{array}{l}\text { Tinggi MA } \\
\text { pada bak }\end{array}$ & $h f$ & 0,65 & $\mathrm{~m}$ \\
\hline Lebar bak & $B f$ & 5 & $\mathrm{~m}$ \\
\hline $\begin{array}{l}\text { Volume desain } \\
\text { bak }\end{array}$ & $V f$ & 19,11 & $\mathrm{~m}^{3}$ \\
\hline
\end{tabular}

\section{Perencanaan pipa pesat (Penstock)}

Penstock adalah saluran penghubung antara bak penenang (forebay) menuju turbin. Pipa ini direncanakan untuk dapat menahan tekanan tinggi.

Tabel 6. Rekapitulasi Perhitungan Penstock

\begin{tabular}{|l|c|c|c|}
\hline \multicolumn{1}{|c|}{ Parameter } & Notasi & Nilai & Satuan \\
\hline Diameter penstok & $\mathrm{D}$ & 0,85 & $\mathrm{~m}$ \\
\hline Tebal penstok & $\delta$ & 0,008 & $\mathrm{~m}$ \\
\hline
\end{tabular}

\section{Pemilihan Turbin}

Faktor yang menentukan dalam merencanakan jenis turbin adalah besar debit rencana dan beda tinggi. Dengan debit sebesar $1,70 \mathrm{~m}^{3} /$ detik dan beda tinggi sebesar 3,56 m maka dipilih turbin Crossflow. Turbin Crossflow adalah salah satu turbin yang sangat berguna bagi PLTMH, yang mana semprotan airnya menumbuk turbin pada dua tempat, sehingga kecepatan air yang keluar sangat kecil.

Setiap turbin mempunyai kecepatan putar tertentu, dimana turbin tersebut akan beroperasi dengan efisiensi terbaik pada kombinasi head dan debit tertentu.

Dari spesifikasi turbin yang digunakan, nantinya akan diperoleh nilai efisiensi turbin yaitu nilai keefektifan turbin yang didapat dengan membandingkan besar daya turbin dengan besar daya air. 


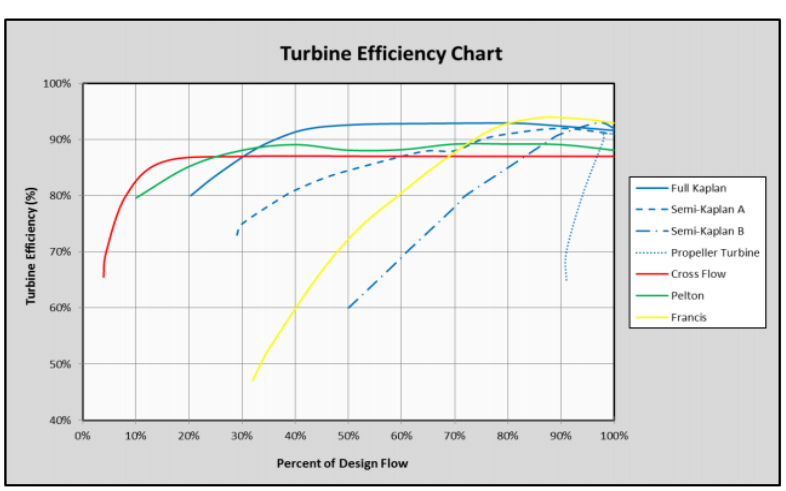

Gambar 4. Grafik Efisiensi Turbin (Sumber: Nusantara, 2015)

Tabel 7. Rekapitulasi Komponen Turbin

\begin{tabular}{|l|c|c|c|}
\hline \multicolumn{1}{|c|}{ Parameter } & Notasi & Nilai & Satuan \\
\hline Turbin & \multicolumn{1}{|c|}{ Turbin Crossflow } \\
\hline Kecepatan spesifik & $N s$ & 120 & $\mathrm{rpm}$ \\
\hline $\begin{array}{l}\text { Kecepatan pada } \\
\text { turbin }\end{array}$ & $N$ & 76,16 & $\mathrm{rpm}$ \\
\hline Efisiensi turbin & $\eta$ & 0,87 & - \\
\hline
\end{tabular}

8. Saluran pembuangan (Tailrace)

Saluran pembuangan berfungsi untuk mengalirkan debit air yang keluar dari turbin air untuk kemudian dibuang ke saluran irigasi. Saluran ini dimensinya harus sama atau lebih besar daripada saluran pemasukan mengingat adanya kemungkinan perubahan mendadak dari debit turbin air.

Tabel 8. Rekapitulasi Perhitungan Tailrace

\begin{tabular}{|l|c|c|c|}
\hline \multicolumn{1}{|c|}{ Parameter } & Notasi & Nilai & Satuan \\
\hline Debit rencana & $Q_{\text {andalan }}$ & 1,70 & $\mathrm{~m}^{3} /$ detik \\
\hline Kecepatan & $v$ & 0,5 & $\mathrm{~m} /$ detik \\
\hline $\begin{array}{l}\text { Koefisien } \\
\text { manning }\end{array}$ & $n$ & 0,015 & - \\
\hline Lebar saluran & $b$ & 3 & $\mathrm{~m}$ \\
\hline Tinggi saluran & $h$ & 1,5 & $\mathrm{~m}$ \\
\hline $\begin{array}{l}\text { Kemiringan } \\
\text { dasar saluran }\end{array}$ & $S$ & 0,0001188 & - \\
\hline Tinggi jagaan & $w$ & 0,6 & $\mathrm{~m}$ \\
\hline
\end{tabular}

\section{Estimasi Kehilangan Energi}

Dalam perjalanan air mengalir dari pintu pengambilan hingga pipa pesat, akan terjadi kehilangan energi seperti kehilangan energi karena saringan kasar, kehilangan energi pada entrace, kehilangan energi karena gesekan sepanjang pipa, dan kehilangan energi karena belokan pipa.

1. Kehilangan energi karena saringan kasar

Hal 80
Direncanakan saringan kasar profil oval dengan lebar profil dari arah aliran $1 \mathrm{~cm}$ dan jarak $5 \mathrm{~cm}$. Kehilangan energi yang terjadi adalah:

$$
\begin{aligned}
H_{r}=\varphi\left(\frac{s}{b}\right)^{\frac{4}{3}} & \frac{v^{2}}{2 g} \sin \alpha \\
& =1,67\left(\frac{0,01}{0,05}\right)^{\frac{4}{3}} \frac{0,6^{2}}{2 \times 9,81} \sin 70 \\
& =0,0037 \mathrm{~m} \\
\text { dimana: } & \\
\mathrm{H}_{\mathrm{r}} & =\text { kehilangan energi karena saringan kasar } \\
(\mathrm{m}) & \\
\varphi & =\text { koefisien profil }(1,67) \\
\mathrm{s} & =\text { lebar profil dari arah aliran }(\mathrm{m}) \\
\mathrm{b} & =\text { jarak antar profil saringan }(\mathrm{m}) \\
\mathrm{v} & =\text { kecepatan aliran (m/detik) } \\
\mathrm{g} & \left.=\text { gaya gravitasi (m/detik }{ }^{2}\right) \\
\alpha & =\text { sudut kemiringan saringan } \\
\mathrm{K} &
\end{aligned}
$$

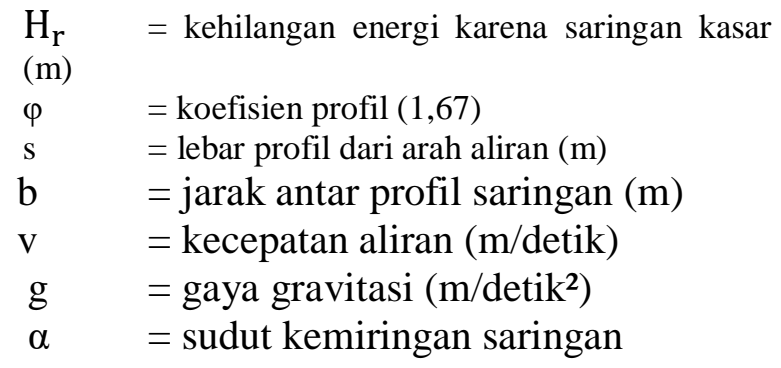

2. Kehilangan energi pada entrance Kehilangan energi pada entrace tergantung dari bentuk mulut entrace.

$$
\begin{aligned}
H_{e} & =K_{e} \cdot\left(\frac{\Delta V^{2}}{2 g}\right) \\
& =0,05\left(\frac{(2,99-0,6)^{2}}{2 \times 9,81}\right) \\
& =0,0146 \mathrm{~m}
\end{aligned}
$$

dimana:

$\mathrm{H}_{\mathrm{e}} \quad=$ kehilangan energi pada entrace $(\mathrm{m})$

$\mathrm{K}_{\mathrm{e}}=$ koefisien bentuk mulut

$\Delta \mathrm{v} \quad=$ selisih kecepatan sebelum dan sesudah entrace ( $\mathrm{m} /$ detik)

g = gaya gravitasi $\left(\mathrm{m} / \mathrm{detik}^{2}\right)$

3. Kehilangan energi karena gesekan sepanjang pipa

Harga f (faktor gesekan) didapat dari diagram Moody sebagai fungsi dari angka Reynold dan kekasaran relatif.

$$
\begin{aligned}
H_{f} & =f \cdot \frac{L}{D} \cdot \frac{v^{2}}{2 g} \\
& =0,015 \times \frac{16}{0,85} \times \frac{2,99^{2}}{2 \times 9,81} \\
& =0,11 \mathrm{~m}
\end{aligned}
$$

dimana:

$H_{f} \quad=$ kehilangan energi sepanjang pipa

(m)

$\mathrm{f} \quad=$ koefisien gesek pipa

$1=$ panjang pipa $(\mathrm{m})$

$\mathrm{v} \quad=$ kecepatan pada pipa (m/detik)

$\mathrm{g} \quad$ = gaya gravitasi $\left(\mathrm{m} /\right.$ detik $\left.^{2}\right)$

D $\quad=$ diameter pipa $(\mathrm{m})$ 
4. Kehilangan energi karena belokan pipa Kehilangan tenaga yang terjadi pada belokan tergantung pada sudut belokan pipa $(\alpha)$.

$$
\begin{aligned}
& H_{I}=K_{b} \frac{v^{2}}{2 g} \\
& \quad=0,025 \times \frac{2,99^{2}}{2 \times 9,81} \\
& \quad=0,011 \mathrm{~m}
\end{aligned}
$$

Dari perhitungan beberapa faktor kehilangan energi pada pipa pesat dapat diketahui kehilangan energi total yaitu:

$$
\begin{aligned}
H_{\text {total }} & =H_{r}+H_{e}+H_{f}+H_{I} \\
& =0,0037+0,0146+0,11+0,011 \\
& =0,14 \mathrm{~m}
\end{aligned}
$$

Nilai ini lebih kecil dari asumsi awal kehilangan energi sebesar $10 \%$ dari tinggi bruto sebesar 0,395 $\mathrm{m}$. Sehingga perencanaan ini dapat digunakan.

5. Perhitungan Energi Listrik

Energi listrik total yang didapat dalam satu tahun dibagi dalam tiga perhitungan. Perhitungan pertama berdasarkan pada $\mathrm{Q}_{85}$ selama $85 \%$ dari satu tahun. Sedangkan 2,5\% selanjutnya direncanakan diantara $\mathrm{Q}_{85}$ dan $\mathrm{Q}_{87,5}$ dan 2,5\% sisanya diantara $\mathrm{Q}_{87,5}$ dan $Q_{90}$. (Soesanto,2010)

Dari grafik diketahui nilai Q yaitu:

$$
\begin{aligned}
& \mathrm{Q}_{85}=1,7 \mathrm{~m}^{3} / \text { detik } \\
& \mathrm{Q}_{87,5}=0,722 \mathrm{~m}^{3} / \text { detik } \\
& \mathrm{Q}_{90}=0,069 \mathrm{~m}^{3} / \text { detik }
\end{aligned}
$$

Efisiensi yang digunakan adalah:

$$
\begin{array}{ll}
\text { efisiensi turbin ( } \mathrm{nt}) & =0,87 \\
\text { efisiensi generator ( } \mathrm{ng}) & =0,95 \\
\text { efisiensi transformator }(\mathrm{ytr}) & =0,95
\end{array}
$$

Sehingga efisiensi total yang digunakan adalah: efisiensi total (ytotal)

$$
\begin{aligned}
& =0,87 \times 0,95 \times 0,95 \\
& =0,79
\end{aligned}
$$

Daya yang didapatkan adalah:

$$
\begin{aligned}
\mathrm{P}_{85} & =\mathrm{y} \times \rho \times \mathrm{g} \times Q_{85} \times H_{\text {eff }} \\
& =0,79 \times 1000 \times 9,81 \times 1,7 \times 3,56 \\
& =46,902 \mathrm{~kW} \\
\mathrm{P}_{87,5} & =\eta \times \rho \times \mathrm{g} \times Q_{87,5} \times H_{\text {eff }} \\
& =0,79 \times 1000 \times 9,81 \times 0,722 \times 3,56 \\
& =19,919 \mathrm{~kW}
\end{aligned}
$$

$$
\begin{aligned}
\mathrm{P}_{90} & =\eta \times \rho \times \mathrm{g} \times Q_{90} \times H_{\text {eff }} \\
& =0,79 \times 1000 \times 9,81 \times 0,069 \times 3,56 \\
= & 1,903 \mathrm{~kW}
\end{aligned}
$$

Energi yang diperoleh adalah:

$$
\begin{aligned}
\mathrm{E}_{1} & =\mathrm{P}_{85} \times 85 \% \times 365 \times 24 \\
& =46,902 \times 0,85 \times 365 \times 24 \\
& =349.232,292 \mathrm{kWh} \\
\mathrm{E}_{2} \quad & =\left(\frac{\mathrm{P}_{85}+\mathrm{P}_{87,5}}{2}\right) \times 2,5 \% \times 365 \times 24 \\
& =\left(\frac{46,902+19,919}{2}\right) \times 0,025 \times 365 \times 24 \\
& =7316,8995 \mathrm{kWh} \\
\mathrm{E}_{3} & =\left(\frac{\mathrm{P}_{87,5}+\mathrm{P}_{90}}{2}\right) \times 2,5 \% \times 365 \times 24 \\
& =\left(\frac{19,919+1,903}{2}\right) \times 0,025 \times 365 \times 24 \\
& =2389,5 \mathrm{kWh}
\end{aligned}
$$

Jadi total energi keseluruhan yang diperoleh dalam satu tahun:

$$
\begin{array}{cl}
\mathrm{E}_{\text {total }} & =\mathrm{E}_{1}+\mathrm{E}_{2}+\mathrm{E}_{3} \\
= & 349.232,292 \mathrm{kWh}+7316,8995 \mathrm{kWh}+ \\
& 2389,5 \mathrm{kWh} \\
= & 358938,69 \mathrm{kWh} \\
& \text { V. PENUTUP }
\end{array}
$$

Dari hasil analisa perhitungan, maka diperoleh kesimpulan bahwa:

1. Berdasarkan hasil perhitungan, diperoleh debit andalan sebesar $1,7 \mathrm{~m}^{3} /$ detik

2. Tinggi efektif yang digunakan dalam perencanaan PLTMH di Saluran Irigasi Mataram ini adalah 3,56 m

3. Bangunan sipil yang digunakan pada PLTMH di Saluran Irigasi Mataram ini adalah bangunan pengatur tinggi muka air, pintu pengambilan (intake), saluran pembawa (headrace), bangunan ukur, bak penenang (forebay), pipa pesat (penstock), dan saluran pembuang (tailrace)

4. Kehilangan energi yang terjadi pada PLTMH ini adalah sebesar 0,14 m. Nilai ini lebih kecil dari asumsi awal kehilangan energi sebesar $10 \%$ dari tinggi bruto sebesar 0,395 m.

5. Energi listrik yang dihasilkan dari PLTMH di Saluran Irigasi Mataram sebesar 85\% sepanjang tahun adalah 358938, $69 \mathrm{kWh}$. 


\section{UCAPAN TERIMA KASIH}

Penulis mengucapkan terima kasih kepada Balai Besar Wilayah Sungai Serayu-Opak Yogyakarta yang telah memberikan pinjaman data guna penyelesaian tugas akhir.

\section{DAFTAR PUSTAKA}

[1] Budiyanto, MA. 2013. Materi kuliah: Hidrologi Terapan-Analisa Debit Andalan dan Debit Banjir, Yogyakarta

[2] Eko, Galih. 2011. Laporan Tugas Akhir: Pemanfaatan Beda Energi Pada Bangunan Terjun Sebagai Pembangkit Listrik Tenaga Mikrohidro. Surabaya

[3] Kusdiana, D. 2008. Pedoman Teknis Standardisasi Peralatan dan Komponen Pembangkit Listrik Tenaga Mikrohidro (PLTMH). Jakarta: Direktorat Jenderal Listrik dan Pemanfaatan Energi Departemen Energi dan Sumber Daya Mineral

[4] Nusantara, DAD. 2015. Materi kuliah: Hydropower Plant-PLTA, Surabaya 